\title{
Desulfuromonas chloroethenica sp. nov. Uses Tetrachloroethylene and Trichloroethylene as Electron Acceptors
}

\author{
LEE R. KRUMHOLZ* \\ Department of Botany and Microbiology, University of Oklahoma, Norman, Oklahoma 73019
}

\begin{abstract}
Strain TT4B, isolated from freshwater sediments contaminated with chlorinated ethylenes, is described as Desulfuromonas chloroethenica sp. nov. This organism grows with acetate or pyruvate as electron donors and tetrachloroethylene, trichloroethylene, fumarate, polysulfide, and Fe(III) nitriloacetate as electron acceptors. $D$. chloroethenica is unique among the desulfuromonads in using chloroethylenes as electron acceptors. It is phenotypically and phylogenetically most closely related to Desulfuromonas acetexigens and shares many other features with this species.
\end{abstract}

In recent years, several novel organisms which couple the oxidation of hydrogen to the reduction of tetrachloroethylene (PCE) and trichloroethylene have been isolated $(3,4,7,8)$. These strains produce ethene or cis-dichloroethylene as well as chloride. We have recently described a strain (5) which uses a similar metabolic strategy but obtains electrons through the complete oxidation of acetate. It has been indicated by $16 \mathrm{~S}$ rRNA sequence analysis (GenBank accession no. U49748) that this organism, strain TT4B, is most closely affiliated with Desulfuromonas acetexigens within the Desulfuromonas/Pelobacter phylogenetic cluster (6). However, until recently we had been unable to demonstrate the reduction of sulfur by this new dechlorinating strain. In this report, I provide additional characterization data for strain TT4B, including the demonstration that polysulfide can be used as an electron acceptor. Based on the criteria for the genus Desulfuromonas, this organism can now be placed in this genus and described as a new species.

Although several new strains have been shown to grow with PCE as an electron acceptor, there have been few studies, if any, testing known strains for this ability. With this in mind, I have cultivated $D$. acetexigens strains DSM 8987 and DSM 8988 with polysulfide as an electron acceptor and Geobacter metallireducens with $\mathrm{Fe}$ (III) nitrilotriacetate (NTA) as an electron acceptor. In both cases, cells were grown with acetate in the mineral medium used for the cultivation of strain TT4B (5). Under these conditions, none of these three strains reductively dechlorinated PCE, when it was present in a hexadecane phase (5), instead of polysulfide or Fe(III) NTA. These results suggest that strain TT4B is unique among its known phylogenetic relatives in that it has developed the ability to use chlorinated ethylenes as respiratory electron acceptors.

Strain TT4B uses only acetate or pyruvate as electron donors and PCE, trichloroethylene, fumarate and Fe(III) NTA as electron acceptors (5). Many other chlorinated compounds have been tested as electron acceptors but were not used. These include tetrachloroethanes, 1,4-dichlorobenzene, $\mathrm{CCl}_{4}$ and $\mathrm{CHCl}_{3}$ (5). Several chlorophenolic compounds were more recently tested; however, none were observed to be dechlorinated, as determined by high pressure liquid chromatographic analysis $\left(\mathrm{C}_{18}\right.$ column with sodium acetate $[\mathrm{pH} 4.5]$-acetonitrile $[1: 1])$. The tested compounds included $(100 \mu \mathrm{M}$ each) 3-chlorophenol, 4-chlorophenol, 3,4-dichlorophenol, and 2,4-dichlorophenol.

A polysulfide solution was prepared by adding $10 \mathrm{~g}$ of $\mathrm{Na}_{2} \mathrm{~S}$.

\footnotetext{
* Mailing address: Department of Botany and Microbiology, 770 Van Vleet Oval, University of Oklahoma, Norman, OK 73019.
}

$9 \mathrm{H}_{2} \mathrm{O}$ and $3 \mathrm{~g}$ of sulfur to $15 \mathrm{ml}$ of water, flushing with $\mathrm{N}_{2}$ in a closed serum bottle, and autoclaving. This preparation was recently tested as an electron acceptor with strain TT4B (1 ml per liter of culture, $6 \mathrm{mM} \mathrm{S}$ ). The polysulfide was reduced over a 3-week incubation period. Sulfide production was determined colorimetrically (1) (Table 1). Acetate consumption, as well as sulfide production, was determined after growth on one or both of these compounds. Growth, as measured by an increase in cell numbers, consumption of acetate, and production of sulfide, occurred only with both compounds present in the growth medium. Sulfate was not produced during growth on polysulfide. When polysulfide was added at $30 \mathrm{mM}$, no growth was observed, due presumably to the toxicity of residual sulfide.

Sulfuroxy anions including sulfate, thiosulfate, and sulfite (10 $\mathrm{mM}$ each as sodium salts) were tested as electron acceptors; however, no growth was observed.

To more fully explore the range of electron donors used by this organism and for a comparison with other sulfur-reducing bacteria, a number of additional common electron donors were included in media with PCE. These donors included malate, glutamate, propionate, and propanol (10 $\mathrm{mM}$ each). Neither growth nor dechlorination of PCE was observed with any of the above electron donors. $D$. acetexigens was also tested with the above compounds as electron donors. Similarly, neither strain of $D$. acetexigens would grow on polysulfide with the above electron donors. Acetate-grown controls always showed growth and polysulfide reduction.

Difference spectra (dithionite reduced minus air oxidized) from membranes of strain TT4B were obtained to determine the presence of cytochromes. Cells were grown on acetate and fumarate (5), harvested by centrifugation, and broken through the use of a French pressure cell. Membranes were prepared from this crude extract by ultracentrifugation at $100,000 \times g$ for $1 \mathrm{~h}$. Absorbance maxima determined with a UV-Vis scanning spectrophotometer (UV2101 PC; Shimadzu) were at 553 $\mathrm{nm}$ ( $\alpha$ band), $524 \mathrm{~nm}$ ( $\beta$ band), and $424 \mathrm{~nm}$ (soret band). These results suggest that one or more cytochromes, possibly of the $c$ type, may be important in respiration by this organism. The electron transport components of strain TT4B are not significantly different from those of $D$. acetexigens, which showed bands at 553,523 and $418 \mathrm{~nm}$ (2).

Strain TT4B differs from other species of Desulfuromonas in that it can utilize PCE and trichloroethylene as respiratory electron acceptors for growth. Some species use other electron donors, including ethanol and lactate (9); however, strain TT4B uses only acetate and pyruvate. Strain TT4B shares many features with the other desulfuromonads, including size, 
TABLE 1. Acetate consumption coupled with polysulfide reduction during growth of strain TT4B

\begin{tabular}{lcccc}
\hline \multicolumn{1}{c}{$\begin{array}{c}\text { Electron donor or } \\
\text { acceptor }\end{array}$} & \multicolumn{2}{c}{$\begin{array}{c}\text { Cell concn (cells } \\
\left.\mathrm{ml}^{-1}\right)^{a}\end{array}$} & $\begin{array}{c}\text { Acetate } \\
\text { consumed } \\
(\mathrm{mM})\end{array}$ & $\begin{array}{c}\text { Sulfide } \\
\text { produced } \\
(\mathrm{mM})\end{array}$ \\
\cline { 2 - 3 } & Initial & Final & & \\
\hline Acetate & & & \\
Polysulfide & $\mathrm{ND}^{c}$ & $\begin{array}{c}6.7 \times 10^{5} \\
\mathrm{ND}\end{array}$ & 0.20 & \\
Acetate and polysulfide & $\mathrm{ND}$ & $1.4 \times 10^{7}$ & 1.63 & 3.73 \\
\hline
\end{tabular}

${ }^{a}$ Cells were counted by epifluorescence microscopy after filtration $(0.2-\mu \mathrm{m}$ pore size) and staining with a $0.01 \%$ acridine orange solution.

${ }^{b}$ Acetate was included at $10 \mathrm{mM}$.

${ }^{c}$ Cell counts could not be determined in the presence of polysulfide.

shape, temperature optimum, and range of electron acceptors. A single subpolar flagellum is present on most cells as viewed by electron microscopy in negatively stained (phosphotungstate) preparations. Strain TT4B is phylogenetically unique among the desulfuromonads in that 16S rRNA analysis shows only $96.9 \%$ similarity with its closest known relative, $D$. acetexigens, $93.4 \%$ with $D$. palmitatis, and $91.9 \%$ with $D$. acetoxidans (5).

Other than the above differences and the fact that $D$. acetexigens has a slightly higher $\mathrm{pH}$ optimum, these two species are very similar. They differ from other species of Desulfuromonas mainly in their relatively narrow range of electron donors and their preference for freshwater conditions (9).

Description of Desulfuromonas chloroethenica sp. nov. Desulfuromonas chloroethenica (chlo.ro.e.the'ni.ca. M.L. adj. chloroethenicus, $-a$, -um, pertaining to chloroethene, as the organism utilizes such compound[s] as electron acceptor[s]).

Cells are rod shaped with rounded ends and occur singly, 0.6 $\mu \mathrm{m}$ wide by 1.0 to $1.7 \mu \mathrm{m}$ long. Do not form spores. Gram negative. Flagellum is subpolar.

Strictly anaerobic chemoorganotrophs which grow in a freshwater mineral medium. Acetate or pyruvate can be used as electron donor. Fumarate, polysulfide, Fe(III) NTA, PCE, and trichloroethylene used as electron acceptors for growth. PCE and trichloroethylene are dechlorinated to cis-dichloroethylene and chloride. A drop in the $\mathrm{pH}$ of the medium is observed if adequate bicarbonate is not included (0.35 to $0.7 \%$ ). $\mathrm{pH}$ optimum near 7.4 with growth occurring between 6.5 and 7.4. The temperature range of growth on PCE is 21 to $31^{\circ} \mathrm{C}$.

Habitat is freshwater sediments contaminated with chlorinated ethylenes. Type strain has been deposited in the American Type Culture Collection (accession no. ATCC 700295).

I thank Michael McInerney for helpful comments on the manuscript and Calvin Byre for help with the nomenclature.

\section{REFERENCES}

1. Cline, J. D. 1969. Spectrophotometric determination of hydrogen sulfide in natural waters. Limnol. Oceanogr. 14:454-458.

2. Finster, K., F. Bak, and N. Pfennig. 1994. Desulfuromonas acetexigens sp. nov., a dissimilatory sulfur-reducing eubacterium from anoxic freshwater sediments. Arch. Microbiol. 161:328-332.

3. Gerritse, J., V. Renard, T. M. Pedro Gomes, P. A. Lawson, M. D. Collins, and J. C. Gottschal. 1996. Desulfitobacterium sp. strain PCE1, an anaerobic bacterium that can grow by reductive dechlorination of tetrachloroethylene or ortho-chlorinated phenols. Arch. Microbiol. 165:132-140.

4. Holliger, C., G. Schraa, A. J. M. Stams, and A. J. B. Zehnder. 1993. A highly purified enrichment culture couples the reductive dechlorination of tetrachloroethene to growth. Appl. Environ. Microbiol. 59:2991-2997.

5. Krumholz, L. R., R. Sharp, and S. S. Fishbain. 1996. A freshwater anaerobe coupling acetate oxidation to tetrachloroethylene dehalogenation. Appl. Environ. Microbiol. 62:4108-4113.

6. Lonergan, D. J., H. L. Jenter, J. D. Coates, E. J. Phillips, T. M. Schmidt, and D. R. Lovley. 1996. Phylogenetic analysis of dissimilatory Fe(III)-reducing bacteria. J. Bacteriol. 178:2402-2408.

7. Maymo-Gatell, X., Y. Chien, J. M. Gossett, and S. H. Zinder. 1997. Isolation of a bacterium that reductively dechlorinates tetrachloroethene to ethene. Science 276:1568-1571.

8. Scholz-Muramatsu, H., A. Neumann, M. Meßmer, E. Moore, and G. Diekert. 1995. Isolation and characterization of Dehalospirillum multivorans gen. nov., sp. nov., a tetrachloroethene-utilizing, strictly anaerobic bacterium. Arch. Microbiol. 163:48-56.

9. Widdel, F., and N. Pfennig. 1992. The genus Desulfuromonas and other gramnegative sulfur reducing eubacteria, p. 3379-3389. In A. Balows, H. G. Trüper, M. Dworkin, W. Harder, and K. H. Schleifer (ed.), The prokaryotes. Springer-Verlag, New York, N.Y. 